\title{
Dry mixtures based on aluminate cements for self-leveling floors
}

\author{
Maria Kaddo ${ }^{{ }^{*}}$ \\ ${ }^{1}$ Moscow State University of Civil Engineering, Yaroslavskoe shosse, 26, Moscow, 129337, Russia
}

\begin{abstract}
In this study the results of the structure, shrinkage and physical and mechanical properties of concrete obtained from dry mixes on the base of aluminate cements for self-leveling floors are presented. Principle possibility of obtaining unshrinkable concretes with the formation of ettringite using aluminate cement, gypsum and modern superplasticizers. Studies of free shrinkage of mixed binder showed that binder can be attribute to binders with compensated shrinkage. Cracking resistance of the composition is provided by the fact that the vast expansion in the initial stage of curing and shrinkage of the final stage is in $5 . .10$ times lower than these values for gypsum and portland cement.
\end{abstract}

\section{Introduction}

The complexity and cost of finishing works are very high. As part of the cost of finishing works a significant part -is the cost of mounting of the floors, as the quality of the floors determines not only the aesthetic comfort, but also the functionality of the room.

The floors (especially, the floors of industrial, sports and so on buildings) must have the whole complex of properties: high strength and abrasion resistance, absolute resistance to cracking, dustless, hygienic and etc. The important property of the floors material is technology. The most interesting materials from this point of view are self-leveling floors on the base of aluminate cement [1-8].

Dry mixes for the mounting of floors are widely used subject to strict requirements: the mixture should provide a high flowability and sufficient vitality during all the working process. Requirements may be provided by the introduction of a set of effective additives, so for floors compositions of mixtures include 10 parts or more.

Cement compositions for seamless floor coverings should have a cracking resistance, because the appearance of cracks on the surface of the floors - the main type of defect. The cause of cracking is deformation of the material, cause it stress exceeding the tensile strength not compensated by relaxation processes. Such deformations are arising in the process of curing, and during its exploitation, have a different nature (due to different causes). The main is deformation caused by physical and chemical processes in the curing binder (contraction, expansion), and shrinkage caused by the evaporation of moisture from the cement material immediately after its placement (plastic shrinkage) and in the process

Corresponding author: m.kaddo@yandex.ru 
of curing (drying shrinkage). Drying shrinkage is the main reason for the formation of cracks.

Shrinkage can be of two kinds when concrete is curing, contractual and humid. The contraction almost has no effect on the volume of construction, and leads to an increase in porosity of the concrete. Humid shrinkage is associated with the evaporation of water from the curing concrete and exceeds the contraction in 5-10 times $[9,10]$.

The problem of cracking resistance of thin-film coatings of cement compositions can be solved by binders with controlled shrinkage (expandable binders, whose shrinkage is compensated by the expansion). Resistance to cracking would be higher in the case when expansion and shrinkage are close not only in size, but also in the development time.

Shrinkage can be reduced by reducing of the consumption of cement, or with the use of special cements with expansive agents. For shrinkage compensated concrete can be used organic expanding components in an amount of $0,5-2 \%$ [11-14]. More widespread has expanding mineral supplements, the application of which produce products of hydration and cause the expansion of the system and increase the strength of the cement stone. According to the chemical composition it can be, for example, calcium oxide $\mathrm{CaO}$, the expansion is processing due to the hydration reaction. If sulfoaluminate calcium is used, an expansion is provided by the formation of ettringite $3 \mathrm{CaO} \cdot \mathrm{Al}_{2} \mathrm{O}_{3} \cdot 3 \mathrm{CaSO}_{4} \cdot 31-32 \mathrm{H}_{2} \mathrm{O}$ $(\mathrm{CASH})$. Using the expanding additive requires a high production standards. Expansion effect depends on many factors and is not stable [15-17].

Analysis of the existing nomenclature of expanding cements and cement shrinkage compensated showed that the most promising use of binders, extension mechanism which is based on the formation of ettringite, as in this case, is associated with more water. The main components of these binders are calcium aluminates.

\section{Materials, methods and mixture proportioning}

While selection of the materials for study were analyzed compositions and properties of the produced aluminate cements. The data on the chemical composition of aluminate cements are given in Table 1.

Table 1. The chemical composition of aluminate concretes, (\%).

\begin{tabular}{|c|c|c|c|c|c|c|}
\hline Composition & $\mathbf{A l}_{\mathbf{2}} \mathbf{O}_{\mathbf{3}}$ & $\mathbf{C a O}$ & $\mathbf{F e}_{\mathbf{2}} \mathbf{O}_{\mathbf{3}}$ & $\mathbf{S i O}_{\mathbf{2}}$ & $\mathbf{S O}_{\mathbf{3}}$ & $\mathbf{R}_{\mathbf{2}} \mathbf{O}$ \\
\hline $\begin{array}{c}\text { CRHAC-75- } \\
0.5 \text { (Russia) }\end{array}$ & $\begin{array}{c}\text { noless } \\
\text { than 75 }\end{array}$ & $\begin{array}{c}\text { nolessthan } \\
20\end{array}$ & $\begin{array}{c}\text { nomorethan } \\
0.5\end{array}$ & $\begin{array}{c}\text { nomoretha } \\
\text { n 1.3 }\end{array}$ & $\begin{array}{c}\text { nomoretha } \\
\text { n 0.15 }\end{array}$ & $\begin{array}{c}\text { nomorethan } \\
0.35\end{array}$ \\
\hline $\begin{array}{c}\text { CRHAC-70-1 } \\
\text { (Russia) }\end{array}$ & $\begin{array}{c}\text { noless } \\
\text { than 70 }\end{array}$ & $\begin{array}{c}\text { noless } \\
\text { than 20 }\end{array}$ & $\begin{array}{c}\text { nomore than } \\
1\end{array}$ & $\begin{array}{c}\text { nomore } \\
\text { than 2 }\end{array}$ & $\begin{array}{c}\text { nomoretha } \\
\text { n 0.15 }\end{array}$ & $\begin{array}{c}\text { nomorethan } \\
0.5\end{array}$ \\
\hline $\begin{array}{c}\text { ISTRA 40 } \\
\text { (Germany) }\end{array}$ & $39-42$ & $37-40$ & $14-17$ & $2-5$ & 0.4 & $\mathrm{MgO} 1.2$ \\
\hline $\begin{array}{c}\text { SECAR 51 } \\
\text { (France) }\end{array}$ & $\begin{array}{c}50.8- \\
54.2\end{array}$ & $\begin{array}{c}35.9- \\
38.9\end{array}$ & $1.5-2.5$ & $4.0-5.5$ & & $\begin{array}{c}\mathrm{MgO}^{2}<1.0 \\
\mathrm{TiO}_{2}<4.0 \\
\mathrm{~K}_{2} \mathrm{O}+\mathrm{Na}_{2} \mathrm{O} \\
<0.5\end{array}$ \\
\hline
\end{tabular}

Corrosion resistant high alumina cement (CRHAC) was selected for study, because it contains at least $70 \% \mathrm{Al}_{2} \mathrm{O}_{3}$. The chemical composition of used cement: $\mathrm{Al}_{2} \mathrm{O}_{3}-70,5 \%$, $\mathrm{CaO}-28,1 \%, \mathrm{SiO}_{2}-0,87 \%, \mathrm{Fe}_{2} \mathrm{O}_{3}-0,3 \%$. The mineral composition of used cement: calcium aluminate $\left(\mathrm{CA}\right.$ and $\mathrm{CA}_{2}$ ) in the ratio 1:1. As a result of $\mathrm{x}$-ray curing products principally consist of $\mathrm{CAH}_{10}$. In the age of 3 days hydration degree of $\mathrm{CA}$ is about $80-85 \%$, $\mathrm{CA}_{2}$ - about $50 \%$. Selected cement is characterized by high strength. Curing speed is less high compared with other aluminate cements, that corresponds to the task (Table. 2). As a 
second component of binder necessary for expansion, natural gypsum $\left(\mathrm{CaSO}_{4} \cdot 2 \mathrm{H}_{2} \mathrm{O}\right)$ and hemihydrate gypsum $\left(\mathrm{CaSO}_{4} \cdot 0,5 \mathrm{H}_{2} \mathrm{O}\right)$ were used.

Table 2. Technical characteristics of the material.

\begin{tabular}{|c|c|c|c|c|}
\hline Value & $\begin{array}{c}\text { CRHAC - } \\
\mathbf{7 5 - 0 . 5}\end{array}$ & $\begin{array}{c}\text { CRHAC - } \\
\mathbf{7 0 - 1}\end{array}$ & ISTRA 40 & SECAR 51 \\
\hline Specific surface area, $\mathrm{m}^{2} / \mathrm{kg}$ & $\begin{array}{c}\text { no less than } \\
450\end{array}$ & $\begin{array}{c}\text { no less than } \\
450\end{array}$ & $300-340$ & $375-425$ \\
\hline $\begin{array}{c}\text { Curing time: } \\
\text { the beginnig -the end, hour }\end{array}$ & $\begin{array}{c}\text { not earlier } \\
\text { than 2, not } \\
\text { later than 12 }\end{array}$ & $\begin{array}{c}\text { not earlier } \\
\text { than 2, } \\
\text { not later than } \\
12\end{array}$ & $\begin{array}{c}\text { not earlier } \\
\text { than 1, not } \\
\text { later than 5 }\end{array}$ & $\begin{array}{c}\text { not earlier } \\
\text { than 2, not } \\
\text { later than 5 }\end{array}$ \\
\hline $\begin{array}{c}\text { Compressive resistance, } \\
\mathrm{MPa}\end{array}$ & $\begin{array}{c}\text { after 3 days } \\
\text { of curing no } \\
\text { less than 50 }\end{array}$ & $\begin{array}{c}\text { after 3 days } \\
\text { of curing no } \\
\text { less than 50 }\end{array}$ & $\begin{array}{c}\text { after a day } \\
\text { of curing } \\
65-75\end{array}$ & $\begin{array}{c}\text { after a day of } \\
\text { curing 55-85 }\end{array}$ \\
\hline Refractoriness, ${ }^{\circ} \mathrm{C}$ & $\begin{array}{c}\text { no less than } \\
1700\end{array}$ & $\begin{array}{c}\text { no less } \\
\text { than } 1670\end{array}$ & 1270 & $1430-1450$ \\
\hline
\end{tabular}

\section{Results and Discussion}

For experimental verification of the component composition of binder and the type of gypsum were conducted studies in a wide range of ratio of the components at a fixed value of the plasticity of the mixture (Table. 3).

Table 3. Test results of two-component binders of different composition

\begin{tabular}{|c|c|c|c|c|c|c|c|}
\hline CRHAC, $\%$ & $\mathbf{1 0 0}$ & $\mathbf{8 0}$ & $\mathbf{7 0}$ & $\mathbf{6 0}$ & $\mathbf{5 0}$ & $\mathbf{4 0}$ & $\mathbf{0}$ \\
\hline gypsum, \% & $\mathbf{0}$ & $\mathbf{2 0}$ & $\mathbf{3 0}$ & $\mathbf{4 0}$ & $\mathbf{5 0}$ & $\mathbf{6 0}$ & $\mathbf{1 0 0}$ \\
\hline \multicolumn{7}{|c|}{$\mathrm{CaSO}_{4} \cdot 2 \mathrm{H}_{2} \mathrm{O}$} \\
\hline W/C & 0.50 & 0.50 & 0.50 & 0.50 & 0.50 & - & - \\
\hline $\begin{array}{c}\text { compression } \\
\text { strength, MPa }\end{array}$ & 54.5 & 50.2 & 53.1 & 48.4 & 34.6 & - & - \\
\hline \multicolumn{7}{|c|}{$\mathrm{CaSO}_{4} \cdot 0,5 \mathrm{H}_{2} \mathrm{O}$} \\
\hline $\begin{array}{c}\text { W/C } \\
\text { compression } \\
\text { strength, MPa }\end{array}$ & 0.50 & 0.52 & 0.53 & 0.53 & 0.54 & 0.55 & 0.55 \\
\hline
\end{tabular}

Composition contents $60 \ldots 80 \%$ of CRHAC (the amount of gypsum 40 ... 20\%) have a high compression strength. Both in terms of strength and economic reasons more efficient use of natural gypsum. Composition was fixed after 3, 7, 24 and 72 hours. In first hours of hydration was observed rapid formation of $\mathrm{CASH}$, decaying after 24 hours. Number of gypsum in curing system decreases in the same regularity (Table 4).

Table 4. Changes in the phase composition of the system "CRHAC + gypsum", depending on time of hydration.

\begin{tabular}{|c|c|c|c|c|c|c|}
\hline \multirow{3}{*}{$\begin{array}{c}\text { Hydration time, } \\
\text { hour }\end{array}$} & \multicolumn{5}{|c|}{ gypsum } & \multicolumn{3}{c|}{ ettringite } \\
\cline { 2 - 7 } & $7.65 \AA$ & $4.29 \AA$ & $3.075 \AA$ & $9.83 \AA$ & $5.65 \AA$ & $3.89 \AA$ \\
\hline 0 & 100 & 100 & 100 & 0 & 0 & 0 \\
\hline 3 & 32 & 29 & 30 & 50 & 50 & 50 \\
\hline 7 & 18 & 21 & 22 & 83 & 75 & 83 \\
\hline 24 & 13 & 16 & 17 & 90 & 90 & 95 \\
\hline 72 & 0 & 0 & 5 & 100 & 100 & 100 \\
\hline
\end{tabular}


To study the shrinkage mechanism of curing binders and to evaluate the role of evaporation of water in the development of shrinkage was undertaken experiment with simple unfilled systems: gypsum binder, portland cement and "CRHAC + gypsum" $(70 \%+$ $30 \%$ ). Selection of the first two systems was defined as sufficient of their study, and the fact that in the first is observed a rapid formation of a solid skeleton formed of crystalline neoplasms $\left(\mathrm{CaSO}_{4} 2 \mathrm{H}_{2} \mathrm{O}\right)$, and in the second - a solid skeleton is formed of several phases, a large share of which is occupied by phase of gel. So, on the example of these two systems are easier to specify the new features of binder deformation "CRHAC+gypsum" (Table 5).

Table 5. Deformation of the two-component binder (CRHAC:gypsum $=70: 30 ; \mathrm{W} / \mathrm{C}=0,6$; start time of measurement -1.75 hours after mixing)

\begin{tabular}{|c|c|c|c|c|c|}
\hline $\begin{array}{c}\text { Time, } \\
\text { hour }\end{array}$ & $\begin{array}{c}\text { Deformation } \\
\mathbf{m m} / \mathbf{m}\end{array}$ & $\begin{array}{c}\text { Deformation } \\
\mathbf{s p e e d}, \\
\boldsymbol{\mu m} / \mathbf{m} \cdot \mathbf{h}\end{array}$ & Time, hour & $\begin{array}{c}\text { Deformation } \\
\mathbf{m m} / \mathbf{m}\end{array}$ & $\begin{array}{c}\text { Deformation } \\
\mathbf{s p e e d}, \\
\boldsymbol{\mu m} / \mathbf{m} \cdot \mathbf{h}\end{array}$ \\
\hline 0.25 & 0.247 & - & 136 & -0.279 & 1.2 \\
\hline 0.5 & 0.285 & 240 & 150 & -0.321 & 1.5 \\
\hline 2.25 & 0.605 & 90 & 161 & -0.344 & 1.1 \\
\hline 3.5 & 0.600 & 2.4 & 174 & -0.275 & 2.7 \\
\hline 4.75 & 0.607 & 3.2 & 198 & -0.373 & 2.1 \\
\hline 6.25 & 0.604 & 1.0 & 222 & -0.391 & 0.4 \\
\hline 7.75 & 0.605 & 0.3 & 246 & -0.383 & 0.3 \\
\hline 16 & 0.478 & 7.9 & 280 & -0.429 & 1.2 \\
\hline 23 & 0.236 & 17.3 & 295 & -0.450 & 1.1 \\
\hline 42 & 0.159 & 2.1 & 336 & -0.520 & 1.0 \\
\hline 48 & 0.155 & 0.33 & 352 & -0.604 & 3.5 \\
\hline 54 & 0.147 & 0.66 & 419 & -0.604 & 0 \\
\hline 63 & 0.146 & 0.11 & 540 & -0.886 & 2.3 \\
\hline 89 & -0.185 & 6.3 & 565 & -0.886 & 0 \\
\hline 114 & -0.273 & 1.76 & 590 & -0.900 & 0.02 \\
\hline 126 & -0.303 & 1.5 & 725 & -0.924 & 0.01 \\
\hline
\end{tabular}

Deformation of curing two-component $($ CRHAC + gypsum $=70: 30)$ binder developed as a result of the superposition of two competing processes: the expansion due to the formation of CASH and formation on its basis of the cement stone structure and shrinkage caused by the evaporation of water from the curing composition.

As in the initial period is very active the formation of cement stone structure, we observe the rapid expansion, reaching after $4 . . .5$ hours $-0,6 \mathrm{~mm} / \mathrm{m}$.

As a result, the deceleration rate of hydration, sealing, but not the extension of curing system due to hydration products (indicated by a rapid increase of the strength of the composition after $4 . . .5$ hours after mixing) and the evaporation of water from the cured material, we observe a sharp decline in the rate of expansion $(90 \mu \mathrm{m} / \mathrm{m} \cdot \mathrm{h}$ to 0$)$, and then the resulting transition effect process after $5 . .6$ hours from expansion to shrinkage. Although at this time, continues the process of expansion by hydration of the remaining share of $\mathrm{CA}$ and, in particular, $\mathrm{CA}_{2}$. After $3 \ldots 4$ days the rate of shrinkage is stabilized $(1 \ldots 2 \mu \mathrm{m} / \mathrm{m} \cdot \mathrm{h})$ and the initial expansion is compensated by shrinkage. The shrinkage of the composition is terminated after $10 \ldots 12$ days at a value of shrinkage of $0.8 \ldots 0.9 \mathrm{~mm} / \mathrm{m}$. (to compare according to our measurements of Portland cement, it is about $8 \ldots 10$ times higher).

Using aluminate cement as a main component for dry mixtures for self-leveling floors requires an adequate selection of the superplasticizer. 
Commercially available additives for use with aluminate cement to produce dry mixtures for floors were analyzed. Supplements of three main groups were selected for study: polymeric sulfomelamin (Peramin SMF20 Perstorp Construction Chemicals Inc., Sweden) modified with polyethylene glycol (Melflux PP100F, Melflux PP200F, SKV Polymers GmbH, Germany) and polycarboxylate (Sika Viscocrete 105P, Swiss). Evaluating of the effectiveness of the superplasticizer joint venture was carried out in accordance with GOST 30459-2008 Admixtures for concretes and mortars. Determination and estimate of efficiency. (EN 934-6:2002 Admixtures for concrete, mortars and grout Part 6 Sampling, conformity control and evaluation of conformity). All the properties were determined on the samples with dimensions of $4 \times 4 \times 16 \mathrm{~cm}$ according to ASTM and GOST for the tests. Water-reducing effect is $57 \ldots 63 \%$. The study works were done by the equipment of MSUCE.

It is known that using aluminate cements mixtures with superplasticizers a rapidly lose flowability. Cause of this were made studies for saving flowability of mixture after 20, 40 and 60 minutes after mixing. Additives were introduced in the amounts recommended by the manufacturer. Saving flowability (decrease no more than $10 \%$ in 60 minutes) showed only superplasticizers based on polycarboxylate.

The two-component composition based on a two-component binder ("CRHAC + gypsum"), filled with quartz sand (Binder:Sand. $=1: 1,5$ ) and modified by superplasticizers based on polycarboxylates (Sika Viscocrete 105P, Swiss) characterized by the following technological and operational properties:

- saving of self-leveling for $30 \ldots 60$ minutes. after mixing;

- setting time: beginning - $2 \mathrm{~h} 00 \mathrm{~m} \ldots 2 \mathrm{~h} 20 \mathrm{~m}$, end - $3 \mathrm{~h} 00 \mathrm{~m} \ldots 3 \mathrm{~h} 15 \mathrm{~m}$;

- strength of composition: compressive strength after 7 hours - 5 ... $6 \mathrm{MPa}$, after 1 day. 22 ... $25 \mathrm{MPa}$, after 3 days. - $42 \ldots 45 \mathrm{MPa}$;

- flexural strength after 3 days. - $11 \ldots 12 \mathrm{MPa}$;

- average density $-1750 \ldots 1850 \mathrm{~kg} / \mathrm{m}^{3}$.

\section{Conclusion}

Producing dry mixtures for self-leveling floors became possible after the creation of modern superplasticizers, which provide a shear strength. Analysis of the results shows that for dry mixtures (with the use of portland cement) modern superplasticizers based on polycarboxylates work effectively. At the same time, there is no consensus about the factors that have influence on the compatibility of superplasticizers with portland cement, aluminate cement, gypsum and mixtures of these materials.

\section{References}

1. U. Klansek, S. Kravanja,Int. J. of Conc. Str. and Mat., 62, 434 (2006)

2. M.Zajac, J.Skocek, F.Bullerjahn, M.B.Haha,CCR, 84, 62 (2016)

3. F.Winnefeld, B.Lothenbach, CCR,40, 1239 (2010)

4. M.García-Maté, I.Santacruz, Ángeles G. De la Torre, L.León-Reina, Miguel A.G., CCC,34, 684 (2012)

5. L.Pelletier-Chaignat, F.Winnefeld, B.Lothenbach, G.LeSaout, C.J.Müller, C.Famy, CCC,33, 551 (2011)

6. F.P.Glasser,L.Zhang, CCR,31, 1881 (2001)

7. J.Péra,J.Ambroise, CCR, 34, 671 (2004)

8. Q.Zhou, N.B.Milestone, M.Hayes, JHM,136, 120 (2006) 
9. T.Zhang,P.Gao,R.Luo,Y.Guo,J.Wei,Q.Yu,CBM, 662 (2013)

10. G.Bernardo, A.Telesca,G.L.Valenti, CCR,36, 1042 (2006)

11. T.Le-Bihan, J.F.Georgin, M.Michel, J.Ambroise, F.Morestin, CCR,42, 1055 (2012)

12. M.Collepardi,A.Borsoi,S.Collepardi,J.J.Olagot,R.Troli, CCC,27, 704 (2005)

13. F.Rajabipour,G.Sant,J.Weiss, CCR,38, 606 (2008)

14. B.Rongbing,S.Jian, CCR, 35, 445 (2005)

15. Q.Cao,Zhongguo John Ma,CBM,75, 450 (2015)

16. K.Sisomphon, O.Copuroglu, E.A.B. Koenders, CBM, 42, 217 (2013)

17. C.Maltese,C.Pistolesi,A.Lolli,A.Bravo,T.Cerulli,D.Salvioni, CCR,35, 2244 (2005) 